\title{
EVALUATION OF RADIATION SHIELDING OF RBMK-1500 REACTOR SPENT NUCLEAR FUEL CONTAINERS
}

\author{
A. Plukis ${ }^{\text {a }}$, R. Plukiené ${ }^{\text {a }}$, V. Remeikis ${ }^{\text {a }}$, R. Davidonis ${ }^{\text {a }}$, P. Kučinskas ${ }^{\text {a }}$, and \\ D. Ridikas ${ }^{b}$

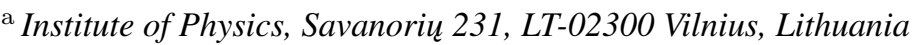 \\ E-mail: rita@ar.fi.lt \\ ${ }^{\mathrm{b}}$ C.E.A. Saclay, DSM/DAPNIA/SPhN, F-91191 Gif-sur-Yvette Cedex, France
}

Received 28 March 2006

\begin{abstract}
The final isotopic composition of spent nuclear fuel (SNF) of the RBMK-1500 reactor depends on the initial enrichment of nuclear fuel, reactor performance parameters, fuel burnup and cooling time. Consequently, different SNF results in different radiation characteristics of the CONSTOR and CASTOR containers, where SNF is temporarily stored. Modelling of nuclide composition and its axial distribution along the fuel channel is done using the Monteburns code system. The MCNP5 code was used for the evaluation of radiation shielding and the surface dose rate of the CASTOR cask. The neutron and gamma spectra for MCNP5 source input are calculated with the ORIGEN-ARP code. The modelling results are compared with existing experimental data of the representative container leading to satisfactory agreement. This result proves the validation of calculation methodology for the radiation shielding safety assessment of CASTOR and similar containers used for the storage of RBMK-1500 SNF.
\end{abstract}

Keywords: spent nuclear fuel, storage containers, radiation dose rate, modelling with Monteburns, MCNP5, SCALE5

PACS: 28.41.Kw, 02.70.Uu

\section{Introduction}

Part of Ignalina Nuclear Power Plant (INPP) spent nuclear fuel (SNF) is stored in the CASTOR and CONSTOR containers [1]. The metallic CASTOR cask is designed for transportation and long-term storage purposes, while heavy concrete-based CONSTOR cask is usually used for the long-term immobile storage. Both of these containers are designed for 50 years with possible extension up to 100-year storage of SNF. To assess the radiation doses outside the containers the composition of SNF must be known and the transport of resulting source neutrons and gamma quanta modelled properly. One has to note that the extension of storage time using these containers depends on the knowledge of the characteristics of SNF and resulting dose rates. Unfortunately, there are few published data on RBMK SNF characteristics. Even the information on neutron fluxes in the fuel elements is not known precisely. Therefore, experimental measurements of dose rates outside the representative storage containers are indispensable despite the powerful modelling tools available today for radiation transport estimates.
In this paper we consider a typical CASTOR cask intended for RBMK-1500 SNF storage, for which radiation dose rates are calculated and compared with experimental results.

\section{Modelling procedure of the RBMK-1500 SNF storage cask CASTOR}

A 3D model of the RBMK-1500 spent nuclear fuel storage container CASTOR, which is shown in Figs. 1 and 2, has been created using the 3D MCNP5 geometry set-up [2]. The geometrical parameters, material properties, and spent nuclear fuel filling history of the container were taken from data of the representative CASTOR container No. 0067-14 [3]. The metallic container CASTOR has a cylindrical shape and is produced from cast iron (Fe $98.28 \%$, C 3.3-3.8\%, Si $1.3-2.6 \%$, $\mathrm{Mn} \leq 0.6 \%, \mathrm{P} \leq 0.03 \%, \mathrm{~S} \leq 0.01 \%, \mathrm{Mg} 0.025-0.09 \%$, $\mathrm{Ni} \leq 1.3 \%, \mathrm{Cu} \leq 0.15 \%, \mathrm{Co} \leq 0.125 \%)$. Stainless steel (Cr 19\%, Mn 2\%, Fe 69.5\%, Ni 9.5\%) was used only for the central rod of the container. The diameter of the cast iron cylinder is $2.08 \mathrm{~m}$, its height is $4.4 \mathrm{~m}$, and wall thickness is $0.3 \mathrm{~m}$. The container is filled with $32 \mathrm{M}$ 

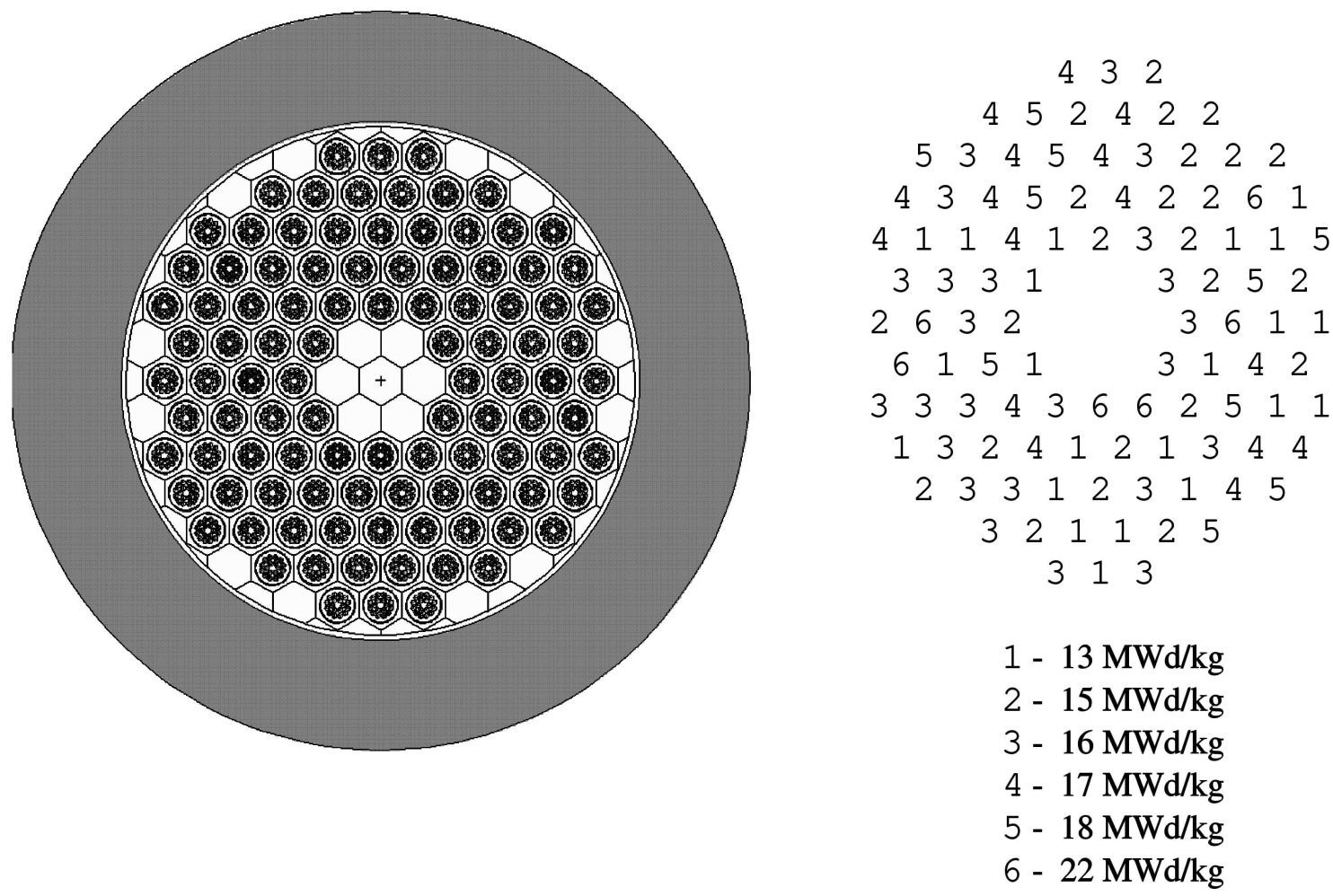

Fig. 1. Cross-section of the SNF container CASTOR modelled with MCNP5 (on the left); the arrangement of the different burnup fuel assemblies, from 13 (label 1) to $22 \mathrm{MW} \mathrm{d} / \mathrm{kg}$ (label 6) (on the right).

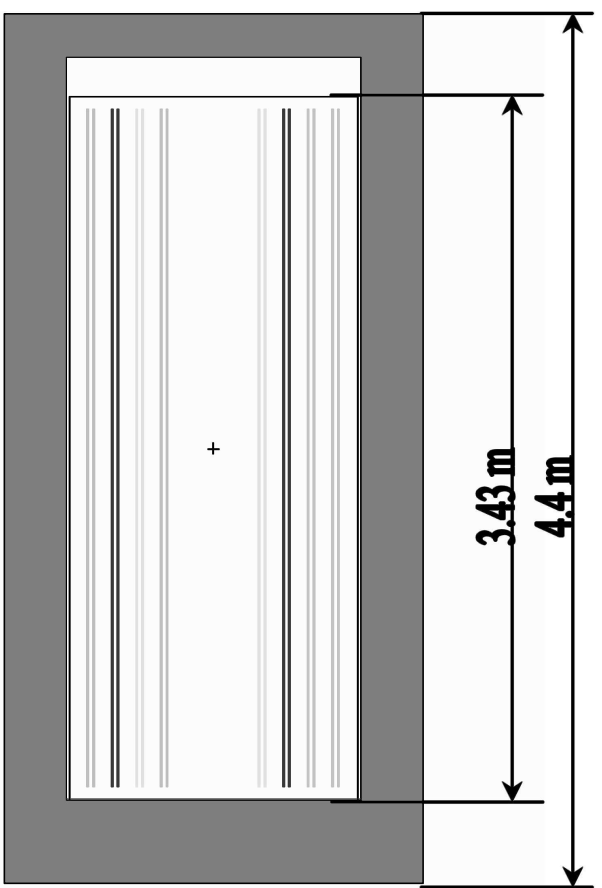

Fig. 2. Longitudinal cut of the CASTOR storage cask.

stainless steel basket where SNF assemblies are placed. This $32 \mathrm{M}$ basket contains 51 fuel assemblies, each of them divided into two equal parts $(341 \mathrm{~cm}$ long). The same baskets are used for the storage of SNF in the storage pool after extraction from the reactor. The burnup

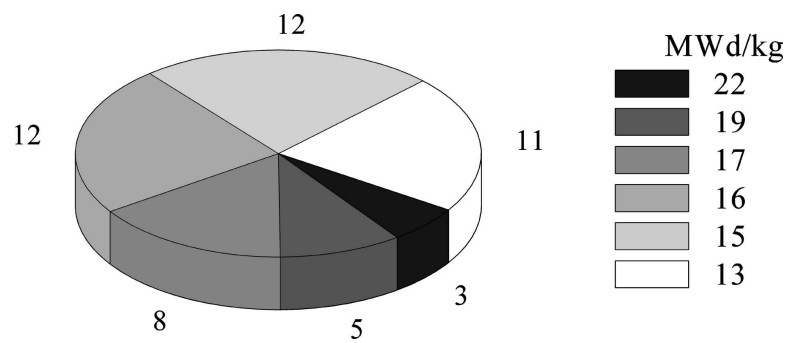

Fig. 3. Amount of different burnup fuel assemblies in the CASTOR storage cask.

of SNF in the container varies from 13 to $22 \mathrm{MW} \mathrm{d} / \mathrm{kg}$. In order to simplify our approach only 6 types of different fuel burnup assemblies were modelled as presented in Fig. 3. 102 different half-assemblies were located in the specified places as reported in the CASTOR container No. 0067-14 history [3]. A cross-sectional view of the CASTOR cask with heterogeneously distributed different fuel assemblies from 13 to $22 \mathrm{MW} \mathrm{d} / \mathrm{kg}$ burnup is presented in Fig. 1.

To perform the calculations several computational codes had to be combined. The CASTOR container was filled with spent nuclear fuel of initial $2 \%{ }^{235} \mathrm{U}$ enrichment. Modelling of SNF nuclide composition and its axial distribution along the fuel channel was done using the Monteburns code system [4] and validated taking into account the experimental data [5]. 


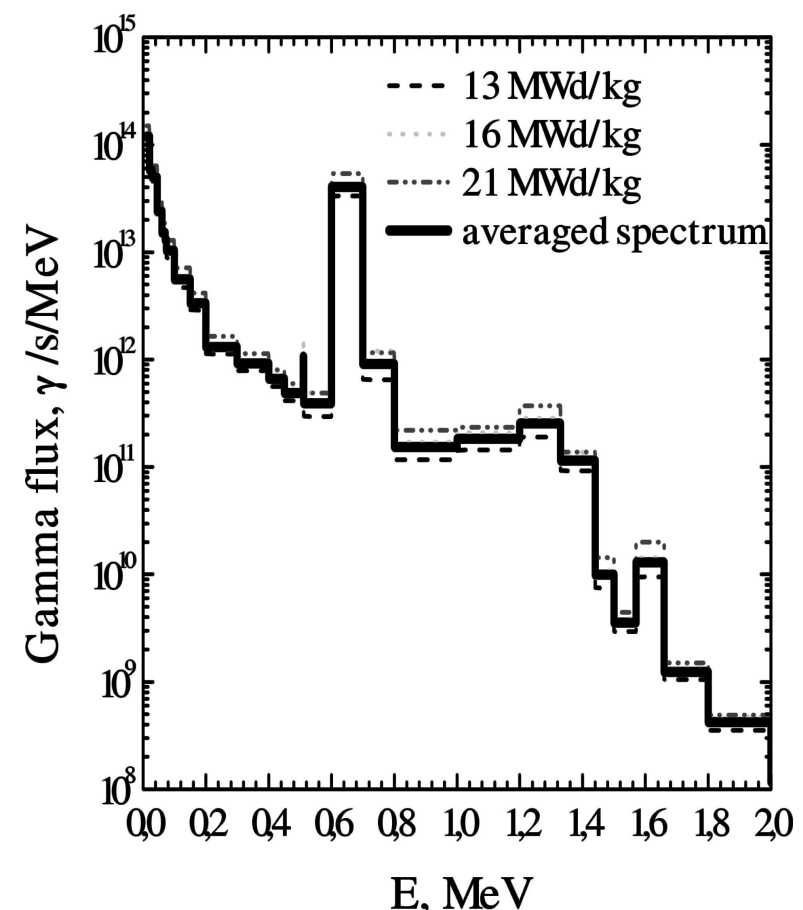

Fig. 4. Gamma source energy spectra for different burnup SNF modelled with ORIGEN-ARP [7] and averaged gamma source energy spectrum.

The results of SNF nuclide composition were already reported in [6]. Afterwards, the gamma and neutron source spectra were calculated with the ORIGEN-ARP code from the SCALE 5 codes package [7]. Finally, MCNP5 was used for neutron and gamma transport and evaluation of radiation dose rates at the surface of CASTOR cask. For the input data MCNP5 requires detailed 3D geometry and particle source description, material composition, their densities, and specific nuclear data. In this case, ENDF/B-VI data library was used for the fuel and structure materials, while JENDL-3.2 data files were employed for fission products.

This particular container No. 0067-14 was also examined experimentally with standard thermo-luminescence (TLD) and Series 1000 MIN-RAD dosimeters. The dose in the TLD attached at 8 points around the CASTOR container was accumulated during the period of 167 hours, resulting in the total measurement uncertainty of $\pm 5-10 \%$. In addition, gamma dose rates were also measured with MIN-RAD at 4 points at the CASTOR cask surface. The precision of MIN-RAD was somewhat worse compared to TLD, i.e., about \pm 10 15\%. The thermo-luminescent dosimeter (TLD 100) uses lithium fluoride $\mathrm{LiF}$ : MnTi. The ${ }^{6} \mathrm{Li}$ abundance in natural $\mathrm{Li}$ causes the thermal neutron sensitivity of LiF detectors. This is because ${ }^{6} \mathrm{Li}$ exhibits large thermal neutron absorption cross-section for the $(\mathrm{n}, \alpha)$ reaction.

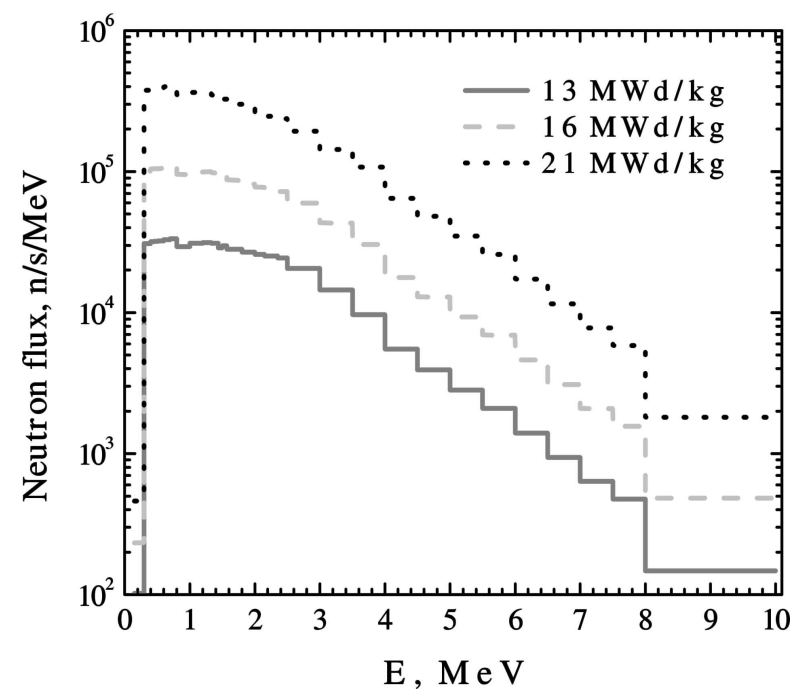

Fig. 5. Neutron source energy spectra for different burnup SNF modelled with ORIGEN-ARP.

According to [8] the TLD sensitivity to thermal neutrons is approximately $13 \%$.

\section{Results}

The isotopic composition in weight percent of the main nuclides important for modelling of neutron and gamma transport is presented in Table 1. Nuclide composition was calculated taking into account the different cooling time for different burnup fuel, which was calculated from the assembly removal from the active core until the experimental measurements of CASTOR casks (see Fig. 1 and Table 1 for details). The average cooling time corresponds to 13 years. A gamma source, resulting from ORIGEN-ARP calculations, for different burnup of RBMK-1500 SNF is presented in Fig. 4. One can see that energy distribution of gamma rays is very similar for every fuel burnup considered. On the other hand, it is seen that the gamma ray intensity is changing moderately with fuel burnup. The difference of the total gamma source intensity between 13 and $22 \mathrm{MW} \mathrm{d} / \mathrm{kg}$ fuel is about $50 \%$.

The neutron spectra are also similar for different cases of fuel burnup as shown in Fig. 5. But the difference between 13 and $22 \mathrm{MW} \mathrm{d} / \mathrm{kg}$ fuel burnup results in the increase in the neutron source intensity nearly by one order of magnitude ( $\sim 8$ times).

As it has been mentioned above, CASTOR is filled with different burnup SNF assemblies. Consequently, the neutron and gamma sources in the cask are distributed heterogeneously. The distribution of gamma and neutron sources according to the 6 types of fuel assemblies in the CASTOR cask is presented in Table 2. 
Table 1. Isotopic composition of main nuclides (wt \%) of different burnup for RBMK-1500 reactor SNF with initial $2 \%{ }^{235} \mathrm{U}$ enrichment, after corresponding cooling time.

\begin{tabular}{ccccccc}
\hline & \multicolumn{5}{c}{ Burnup, MW d/kg } \\
\cline { 2 - 7 } Nuclide & 13 & 15 & 16 & 17 & 19 & 22 \\
\hline${ }^{234} \mathrm{U}$ & $1.26 \cdot 10^{-4}$ & $1.23 \cdot 10^{-4}$ & $1.22 \cdot 10^{-4}$ & $1.17 \cdot 10^{-4}$ & $1.15 \cdot 10^{-4}$ & $1.08 \cdot 10^{-4}$ \\
${ }^{235} \mathrm{U}$ & $7.19 \cdot 10^{-3}$ & $6.31 \cdot 10^{-3}$ & $5.78 \cdot 10^{-3}$ & $5.03 \cdot 10^{-3}$ & $4.59 \cdot 10^{-3}$ & $3.38 \cdot 10^{-3}$ \\
${ }^{236} \mathrm{U}$ & $1.77 \cdot 10^{-3}$ & $1.90 \cdot 10^{-3}$ & $2.02 \cdot 10^{-3}$ & $2.09 \cdot 10^{-3}$ & $2.15 \cdot 10^{-3}$ & $2.31 \cdot 10^{-3}$ \\
${ }^{238} \mathrm{U}$ & $8.57 \cdot 10^{-1}$ & $8.56 \cdot 10^{-1}$ & $8.68 \cdot 10^{-1}$ & $8.54 \cdot 10^{-1}$ & $8.54 \cdot 10^{-1}$ & $8.51 \cdot 10^{-1}$ \\
${ }^{237} \mathrm{~Np}$ & $6.81 \cdot 10^{-5}$ & $8.00 \cdot 10^{-5}$ & $9.04 \cdot 10^{-5}$ & $1.00 \cdot 10^{-4}$ & $1.09 \cdot 10^{-4}$ & $1.36 \cdot 10^{-4}$ \\
${ }^{238} \mathrm{Pu}$ & $1.00 \cdot 10^{-5}$ & $1.36 \cdot 10^{-5}$ & $1.71 \cdot 10^{-5}$ & $2.03 \cdot 10^{-5}$ & $2.34 \cdot 10^{-5}$ & $3.57 \cdot 10^{-5}$ \\
${ }^{239} \mathrm{Pu}$ & $2.25 \cdot 10^{-3}$ & $2.29 \cdot 10^{-3}$ & $2.35 \cdot 10^{-3}$ & $2.33 \cdot 10^{-3}$ & $2.34 \cdot 10^{-3}$ & $2.36 \cdot 10^{-3}$ \\
${ }^{240} \mathrm{Pu}$ & $9.80 \cdot 10^{-4}$ & $1.12 \cdot 10^{-3}$ & $1.25 \cdot 10^{-3}$ & $1.35 \cdot 10^{-3}$ & $1.43 \cdot 10^{-3}$ & $1.63 \cdot 10^{-3}$ \\
${ }^{241} \mathrm{Pu}$ & $1.73 \cdot 10^{-4}$ & $2.10 \cdot 10^{-4}$ & $2.39 \cdot 10^{-4}$ & $2.30 \cdot 10^{-4}$ & $2.43 \cdot 10^{-4}$ & $2.97 \cdot 10^{-4}$ \\
${ }^{242} \mathrm{Pu}$ & $7.73 \cdot 10^{-5}$ & $1.07 \cdot 10^{-4}$ & $1.33 \cdot 10^{-4}$ & $1.62 \cdot 10^{-4}$ & $1.88 \cdot 10^{-4}$ & $2.94 \cdot 10^{-4}$ \\
${ }^{133} \mathrm{Cs}$ & $4.49 \cdot 10^{-4}$ & $4.99 \cdot 10^{-4}$ & $5.42 \cdot 10^{-4}$ & $5.76 \cdot 10^{-4}$ & $6.06 \cdot 10^{-4}$ & $6.96 \cdot 10^{-4}$ \\
${ }^{147} \mathrm{Sm}$ & $1.29 \cdot 10^{-4}$ & $1.38 \cdot 10^{-4}$ & $1.47 \cdot 10^{-4}$ & $1.55 \cdot 10^{-4}$ & $1.60 \cdot 10^{-4}$ & $1.73 \cdot 10^{-4}$ \\
${ }^{16} \mathrm{O}$ & $1.18 \cdot 10^{-1}$ & $1.18 \cdot 10^{-1}$ & $1.20 \cdot 10^{-1}$ & $1.18 \cdot 10^{-1}$ & $1.18 \cdot 10^{-1}$ & $1.18 \cdot 10^{-1}$ \\
\hline Cooling time, years & 12.33 & 11.65 & 11.29 & 13.62 & 13.62 & 13.47
\end{tabular}

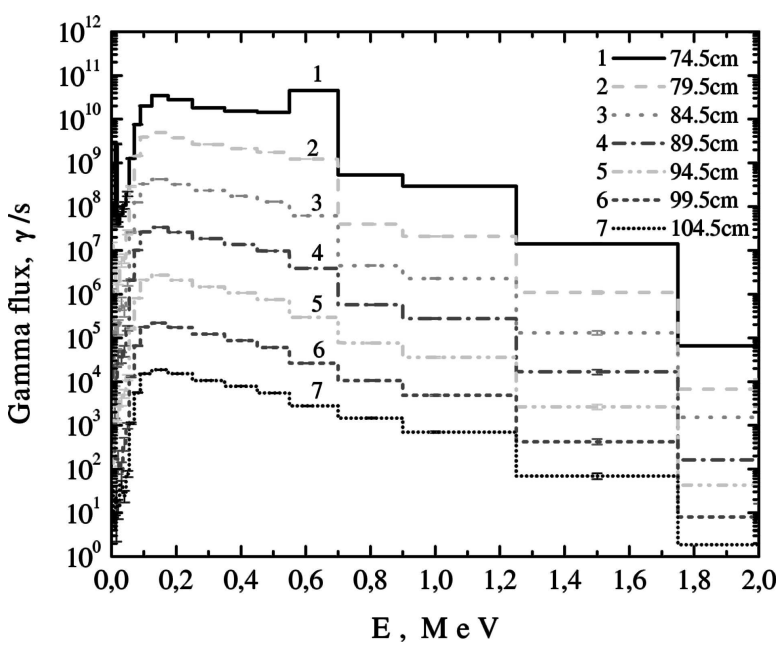

Fig. 6. Absorption of gamma rays in the CASTOR storage cask wall as a function of the wall thickness, counting from the centre of the container.

The total gamma source intensity in the cask is about $1.76 \cdot 10^{16} \mathrm{\gamma} / \mathrm{s}$, and the total neutron source intensity is $\sim 7.62 \cdot 10^{7} \mathrm{n} / \mathrm{s}$. These values were used in our further calculations for normalization of gamma and neutron doses calculated with MCNP5, because MCNP tallies are initially normalized per one starting particle. The average intensity of the gamma source from one fuel assembly is about $3.45 \cdot 10^{14} \mathrm{\gamma} / \mathrm{s}$, which corresponds to $16 \mathrm{MW} \mathrm{d} / \mathrm{kg}$ fuel burnup. The averaged intensity of the neutron source from one fuel assembly is $1.49 \cdot 10^{6} \mathrm{n} / \mathrm{s}$ corresponding to the fuel burnup between 16 and $17 \mathrm{MW} \mathrm{d} / \mathrm{kg}$.

As it was pointed above the complicated geometry of the CASTOR cask with different burnup SNF was described using a hexagonal lattice filled with appropriate assemblies as shown in Fig. 1. In this way the
Table 2. Estimated gamma and neutrons source intensities in the different burnup fuel assemblies and total intensities in the CASTOR storage cask.

\begin{tabular}{cccc}
\hline $\begin{array}{c}\text { Burnup, } \\
\text { MW d/kg }\end{array}$ & $\begin{array}{c}\text { Number } \\
\text { of assemblies }\end{array}$ & Gammas/s & Neutrons/s \\
\hline 13 & 11 & $3.21 \cdot 10^{15}$ & $6.91 \cdot 10^{6}$ \\
15 & 12 & $3.98 \cdot 10^{15}$ & $1.19 \cdot 10^{7}$ \\
16 & 12 & $4.32 \cdot 10^{15}$ & $1.63 \cdot 10^{7}$ \\
17 & 8 & $2.88 \cdot 10^{15}$ & $1.43 \cdot 10^{7}$ \\
18 & 5 & $1.89 \cdot 10^{15}$ & $1.15 \cdot 10^{7}$ \\
22 & 3 & $1.31 \cdot 10^{15}$ & $1.54 \cdot 10^{7}$ \\
\hline Total in & 51 & $1.76 \cdot 10^{16}$ & $7.62 \cdot 10^{7}$ \\
CASTOR & & & \\
\hline
\end{tabular}

heterogeneous distribution of SNF half-assemblies is obtained. The dose rate calculations were performed with MCNP5 using ring detector option for two different particle source descriptions: homogeneous gamma and neutron source distribution of $16 \mathrm{MW} \mathrm{d} / \mathrm{kg} \mathrm{SNF}$ in all 102 half-assemblies and heterogeneous distribution taking into account different burnup SNF assemblies according to the existing irradiation history.

The absorption of gamma rays in the $31 \mathrm{~cm}$ thick CASTOR cask wall is presented in Fig. 6. The CASTOR wall was divided into 7 regions every $5 \mathrm{~cm}$ in order to observe attenuation of gamma rays and to determine the importance of gamma ray transport in each region. In Fig. 6 one can see that photon flux in the absolute value in the last region of the CASTOR wall decreases nearly by 10 orders of magnitude in the low energy range, while somewhat smaller attenuation is observed for high energy photons. The energy distribution of the photons also changes considerably: penetrating the first $5 \mathrm{~cm}$ of the wall the low 


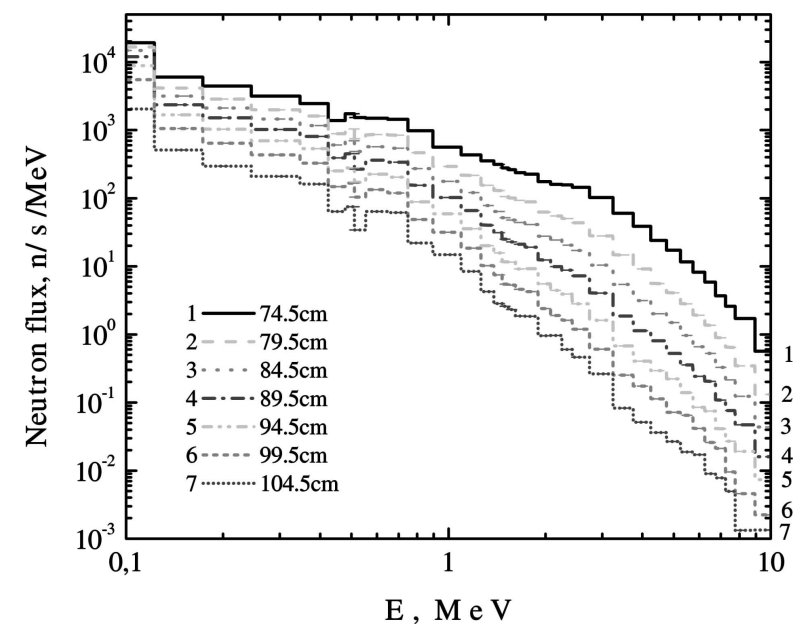

Fig. 7. Neutron moderation in the CASTOR storage cask wall as a function of the wall thickness, counting from the centre of the container.

energy photons are totally cut and the intensity of the flux drastically decreases. For this reason specific variance reduction techniques were needed to increase the statistics of Monte Carlo calculations. For example, the photon tracking transport importance in MCNP5 was gradually increased from 1 to $10^{6}$ starting from the initial to the outside wall of the cask; otherwise it would be impossible to obtain a statistically significant result in a reasonable computing time.

Neutrons generated in spent nuclear fuel are continuously moderated and attenuated in the iron wall of the container. The neutron moderation in the CASTOR cask wall as a function of the wall thickness is presented in Fig. 7. The absolute value of the total neutron flux in the last region of the CASTOR wall decreases by a factor of 27 . The neutron spectrum at the container surface is considerably changed - the fast neutron part is reduced by 3 orders of magnitude compared to the thermal neutron part, which is reduced by a factor of 22 and which is the major contributor to the total neutron dose at the surface.

The gamma dose is mainly determined by the fission products $\left({ }^{137} \mathrm{Cs},{ }^{134} \mathrm{Cs},{ }^{106} \mathrm{Rh}\right.$, etc.) and by the neutron activation products such as ${ }^{60} \mathrm{Co}$, etc. Taking into account the information about impurities from Ref. [9], in modelling it is assumed that Co concentration in the fuel assembly construction materials ( $\mathrm{ZrNb}$ alloys, stainless steel) is $1.05 \mathrm{~g}$ (0.04 g in the fuel cladding material, $0.71 \mathrm{~g}$ in the spacer grid, and $0.3 \mathrm{~g}$ of Co from deposits of activated corrosion products of one fuel assembly). It is well known that the nuclide concentration depends on the fuel burnup and cooling time after the removal from the active core. As it has been reported above, according to the documentation, the cooling time differs for the fuel assemblies of different burnup from 11 to 14 years, and the average cooling time is $\sim 13$ years at the time when the measurements have been performed.

The results of gamma dose rates at the surface of the CASTOR cask calculated with MCNP5 ring detector option are presented in Fig. 9. The experimental data measured with TLD and MIN-RAD dosimeters are presented in circles and triangles, respectively. The MCNP5 modelling results are also compared to SCALE 4.3 predictions from Ref. [1]. We note that gamma dose rates obtained from Monte Carlo simulations even taking into account the neighbouring containers (we assumed the gamma dose rate from the similar container surface at $1 \mathrm{~m}$ distance $(11.8 \mu \mathrm{Sv} / \mathrm{h})$ and added to the calculated surface dose rate $(26.8 \mu \mathrm{Sv} / \mathrm{h}))$ give a somewhat smaller average value of $38.6 \pm$ $0.4 \mu \mathrm{Sv} / \mathrm{h}$ compared with measurements. All experimental gamma dose points are $\sim 1.6$ times above the MCNP5 calculated average, especially for MIN-RAD measurement at $180^{\circ}$ angle, where the difference is almost 2.5 times. In our opinion, this result is rather good taking into account other uncertainties of our model (spent nuclear fuel composition, irradiation and cooling history, Co contents in the fuel cladding, etc.). In addition, this difference might also be due to the CASTOR container surface contamination with fission products from the cooling pool. The contamination of the surface with $1 \mathrm{kBq} / \mathrm{cm}^{2}$ of ${ }^{137} \mathrm{Cs}$ would increase the dose by $22 \mu \mathrm{Sv} / \mathrm{h}$, and additional investigation should be performed to confirm/deny the eventual surface contamination. In addition, the TLD are sensitive to the thermal neutron flux, which also might explain the increase in the measured gamma dose.

On the other hand, the Monte Carlo calculations agree quite well with independent calculations performed with SCALE 4.3, which have resulted in the $52 \mu \mathrm{Sv} / \mathrm{h}$ dose rate after 10 years of cooling time [1]. The difference in the gamma dose after $\sim 13$ years (our work) and 10 years [1] is determined mainly by ${ }^{106} \mathrm{Rh}$ (daughter of ${ }^{106} \mathrm{Ru}$ ) high energy gammas, which have great influence on the gamma dose due to the higher penetration through the cask walls, and by the ${ }^{60} \mathrm{Co}$ with its relatively short half-life ( $T_{1 / 2}=5.27$ years).

The neutron dose rate at the surface of the CASTOR cask No. 0067-14 calculated with MCNP5 is presented in Fig. 8. The two cases were considered: (a) the case of a homogeneously distributed neutron source of $16 \mathrm{MW} \mathrm{d} / \mathrm{kg}$ fuel burnup, and (b) the case of a heterogeneously distributed neutron source taking into account fuel assemblies of higher burnup. The average 


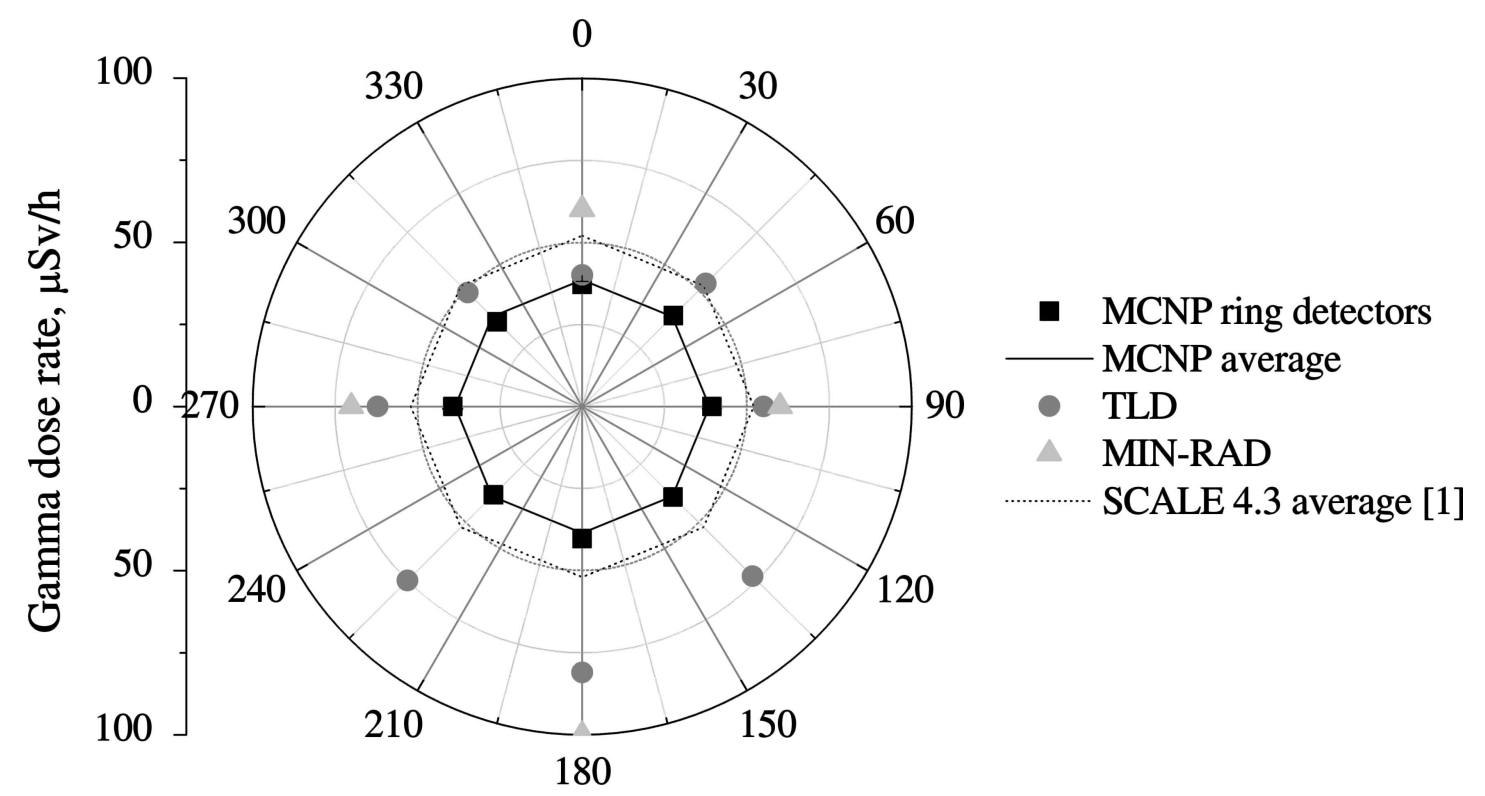

Fig. 8. Angular gamma dose rates at the surface of CASTOR cask No. 0067-14 calculated with MCNP5 $\gamma$ ring detectors against SCALE 4.3 predictions from Ref. [1] and experimental data measured with TLD and MIN-RAD dosimeters (see the legend for details).

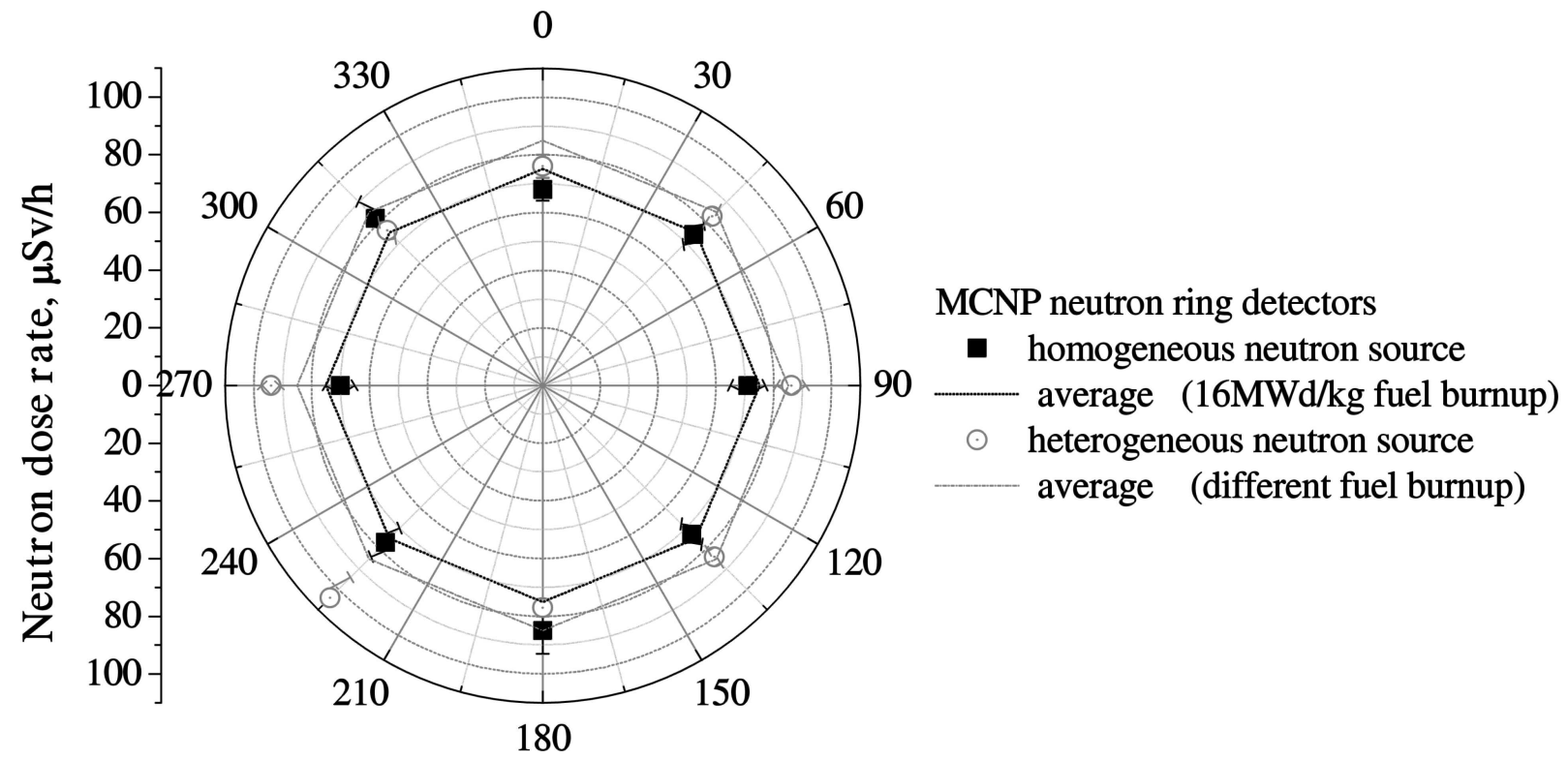

Fig. 9. Angular neutron dose rates at the surface of CASTOR cask No. 0067-14 calculated with MCNP5 in the case of homogeneously distributed neutron source of $16 \mathrm{MW} \mathrm{d} / \mathrm{kg}$ fuel burnup and in the case of heterogeneously distributed neutron source taking into account fuel assemblies of higher burnup (see the legend for details).

neutron dose rate is about $75 \mu \mathrm{Sv} / \mathrm{h}$, and for the homogeneously distributed neutron source of $16 \mathrm{MW} \mathrm{d} / \mathrm{kg}$ fuel burnup the neutron dose rate values vary within the range from 68 to $85 \mu \mathrm{Sv} / \mathrm{h}$. In addition, one can see that for the neutron source even a few assemblies with high burnup can cause observable anisotropy of neutron dose rates. This can be explained by lower neutron attenuation rates compared to gammas both in the absolute value and changes in energy spectra. Indeed, open circles in Fig. 9 represent the neutron dose calcu- lated with the real neutron source of different burnup (from 13 to $22 \mathrm{MWd} / \mathrm{kg}$ ) SNF half-assemblies taking into account the real distribution of their location in the CASTOR cask No. 0067-14. For the heterogeneously distributed neutron source the average neutron dose rate is about $85 \mu \mathrm{Sv} / \mathrm{h}$, and the neutron dose rate values vary within the range from 76 to $104 \mu \mathrm{Sv} / \mathrm{h}$. The local superposition of half-assemblies of higher burnup (16-22 MW d $/ \mathrm{kg}$ ) at the angles of 270 and $220^{\circ}$ resulted in about $28 \mu \mathrm{Sv} / \mathrm{h}$ increase in the neutron dose 
rate. This result confirms that neutron flux distribution is extremely sensitive to the fuel burnup and influences the neutron dose rate calculation results. In conclusion we would like to emphasize that the neutron dose rate calculation should be performed with the real SNF neutron source distribution in the container, because averaged burnup fuel (in our case $16 \mathrm{MW} \mathrm{d} / \mathrm{kg}$ ) causes incorrect results. The measurements of neutron dose rates would be very useful to validate our predictions.

\section{Conclusions}

The neutron and gamma ray sources in the SNF storage cask CASTOR have been estimated using different radiation transport and material evolution code packages such as ORIGEN-ARP, MCNP5, and Monteburns. The neutron dose rate at the surface of the cask varies within the range between 76 and $104 \mu \mathrm{Sv} / \mathrm{h}$. The anisotropy of dose rates is observed for neutrons and is explained by heterogeneous distribution of different burnup fuel assemblies inside the container. The averaged gamma dose rate is $38.6 \pm 0.4 \mu \mathrm{Sv} / \mathrm{h}$ and it is determined mainly by ${ }^{137} \mathrm{Cs}$ and ${ }^{60} \mathrm{Co}$. This result underestimates the corresponding measurements performed with TLD and MIN-RAD dosimeters by $~ 50 \%$. The obtained discrepances might be due to the possible surface contamination, the partial gamma dosimeter sensitivity to neutron flux from the container, etc. Some additional investigations on this subject will be performed in the near future, although in general the agreement between our predictions and measurements is satisfactory. This work validates the methodology of the radiation shielding and dose rate calculations for RBMK SNF storage facilities. However, more experimental data are needed (in particular for other types of storage containers) in order to provide more precise uncertainties of the predicted values.

\section{Acknowledgements}

This research was supported in part by the Lithuanian State Science and Studies Foundation in the frame of the project No. C-19/2006 and by the Lithuanian and French cooperation program Gilibert (No. 09395TB).

\section{References}

[1] A. Šmaižys, P. Poškas, D. Lukauskas, and V. Remeikis, Experimental determination of radiation safety of spent nuclear fuel dry storage casks CASTOR and CONSTOR, Lithuanian J. Phys. 41(4-6), 547-550 (2001).

[2] F.B. Brown, R.F. Barrett, T.E. Booth, J.S. Bull, L.J. Cox, R.A. Forster, J.T. Goorley, R.D. Mosteller, S.E. Post, R.E. Prael, E.C. Selcow, A. Sood, and J. Sweezy, MCNP version 5, Trans. Am. Nucl. Soc. 87(273), LA-UR-023935, LANL (2002).

[3] CASTOR container No. 0067-14 history (INPP, private communication).

[4] H.R. Trellue and D.I. Poston, User's Manual, Version 2.0 for Monteburns, Version 5B, preprint LA-UR-994999 (LANL, 1999).

[5] E.V. Burlakov, C.N. Begichev, A.L. Tataurov, V.M. Kvator, A.B. Davydov, A.V. Stepanov, T.P. Makarova, B.A. Bibichev, V.D. Domkin, E.V. Pevtsova, A.V. Lovtsius, and B.N. Belyaev, Nuclide Composition of the Samples of RBMK-1000 Reactor Spent Nuclear Fuel, preprint IAE-6266/3 (RSC-KI, Moscow, 2003) [in Russian].

[6] R. Plukienè, A. Plukis, V. Remeikis, and D. Ridikas, Benchmark calculations of RBMK spent nuclear fuel isotopic composition using MCNP and ORIGEN codes, Lithuanian J. Phys. 45(4), 281-287 (2005).

[7] S.M. Bowman and L.C. Leal, ORIGEN-ARP: Automatic Rapid Process for Spent Fuel Depletion, Decay, and Source Term Analysis, preprint ORNL / NUREG/CSD2/ V1 / R6 (ORNL, 2000).

[8] S. Croft and C.A. Perks, Corrections to gamma ray dosimetry measurements made in Harwell's two high intensity filtered neutron beams using ${ }^{7} \mathrm{LiF}$ thermoluminescent dosimeters owing to their neutron sensitivity, Radiat. Prot. Dosim. 33(1), 351-354 (1990).

[9] Evaluation of Radiation and Criticality Safety of TUK11-P with 4 RBMK-1500 SNF Assemblies, preprint TASpd-1245-70868 (RFNC-VNIIEF, Sarov, 2003) [in Russian]. 


\title{
RBMK-1500 REAKTORIAUS PANAUDOTO BRANDUOLINIO KURO KONTEINERIŲ RADIACINĖS SAUGOS VERTINIMAS
}

\author{
A. Plukis ${ }^{\text {a }}$, R. Plukiene ${ }^{\mathrm{a}}$, V. Remeikis ${ }^{\mathrm{a}}$, R. Davidonis ${ }^{\mathrm{a}}$, P. Kučinskas ${ }^{\mathrm{a}}$, D. Ridikas ${ }^{\mathrm{b}}$ \\ ${ }^{\text {a }}$ Fizikos institutas, Vilnius, Lietuva \\ ${ }^{\text {b } C . E . A . ~ S a c l a y, ~ G i f-s u r-Y v e t t e, ~ P r a n c u ̄ z i j a ~}$
}

\section{Santrauka}

RBMK-1500 reaktoriaus panaudoto branduolinio kuro (PBK) nuklidinè sudètis priklauso nuo pradinio kuro i̇sodrinimo, darbo režimo bei išdegimo reaktoriuje netolygumų. PBK sudètis savo ruožtu lemia laikino saugojimo konteinerių radiacines savybes.

Nuklidinè sudètis bei išdegimo pasiskirstymo profilis RBMK1500 reaktoriaus kuro rinklèse PBK saugojimo konteineriuose modeliuota Monteburns ir SCALE 5 programu paketais, naudojant RBMK-1000 eksperimentinius duomenis [4]. PBK CASTOR konteinerių radiacinės savybės bei lygiavertė dozė apskaičiuota Monte Karlo skaitiniais metodais MCNP5 programa. Gautieji rezultatai palyginti su reprezentacinio konteinerio eksperimentinių matavimu bei modeliavimo su SCALE 4.3 rezultatais [1]. Apskaičiuota neut- ronų nulemta dozès galia konteinerio paviršiuje yra 76-104 $\mu \mathrm{Sv} / \mathrm{h}$ intervale, o pastebètas dozės galios anizotropiškumas yra itakojamas skirtingo išdegimo rinklių išsidèstymo CASTOR konteineryje. Apskaičiuotą 38,6 $\pm 0,4 \mu \mathrm{Sv} / \mathrm{h}$ gama spindulių dozès galią daugiausia sudaro ${ }^{137} \mathrm{Cs}$ ir ${ }^{60} \mathrm{Co}$. Ši dozès vertè ne visai sutampa su eksperimentinių matavimų rezultatais. Manoma, kad tai lemia tiek dalinis dozimetru jautris šiluminiams neutronams, tiek galimas paviršinis konteinerių užterštumas.

Šis darbas patvirtina, kad siūloma metodika yra tinkama vertinti konteineriu radiacinę saugą RBMK-1500 reaktoriaus PBK saugojimo konteineriams. Apskaičiuotų dozès galios verčiu paklaidoms tiksliau įvertinti reikalingi papildomi eksperimentiniai tyrimai. 